UDC $784.75(075.8)$

DOI https://doi.org/10.24919/2308-4863/38-1-4

Beyimkhanim VALIYEVA, orcid.org/0000-0002-5076-5138

Senior Teacher Azerbaijan National Conservatory (Baku, Azerbaijan)veliyeva_b@mail.ru

\title{
THE IMPORTANCE OF KHAN SHUSHINSKI'S CREATIVITY IN THE DEVELOPMENT OF AZERBAIJANI SINGING SCHOOL (KHANENDE)
}

The article examines the work of Khan Shushinsky (1901-1979), a prominent representative of the Azerbaijani school of singing. Also, the features of Khan Shushinsky's singing style, the possibilities of a wide range of voices, the principles of performing mughams and folk songs, which are a genre of Azerbaijani oral music, were considered. The article notes the unique style of performance, rich repertoire, ability to compose songs based on elements of national music, which arose under the influence of the traditions of the Karabakh singing school of the XIX century under the influence of Khan Shushunsky's work.

The purpose of this research is to determine the principles of Khan Shushinsky's performance, the features of the interpretation of mughams and folk songs, works of the composer in his performance. The main points of the article are the discovery of the peculiarities of Khan Shushinsky's performance opportunities and the definition of his role in the development of the Azerbaijani school of singing in the XX century. The involvement of Khan Shushinsky's reading style, which has not been subjected to scientific and theoretical analysis, in the detailed scientific research is the basis of the research.

The research methodology is based on a musical-analytical, theoretical, and historical analysis, a comprehensive generalization of the research conducted by Azerbaijani musicologists to study the style of singing in the style of mugam performance.

The scientific novelty of the research. The scientific novelty of the research is that, for the first time as special research work, the article is dedicated to the work of Khan Shushinsky, a prominent representative of the Azerbaijani school of singing, and the study of the features of his reading style. At the same time, within the framework of Azerbaijani music science, Khan Shushinsky's creativity and the environment that formed it were approached from the perspective of oriental art, and the singer's performance art was studied in detail.

Conclusions. The art of singing is of special importance in Azerbaijani music culture. It is noted that the singers have preserved folk music and the art of mugam, which are the expression of the spiritual world, intelligence, desires, and aspirations of the people. From this point of view, Khan Shushinsky's creativity is an important force in the development of Azerbaijani folk music culture. It is especially emphasized that Khan Shushinsky, in addition to being a skilled performer, was also a creative artist, the creator of many national folk music genres, tesniph's, and rangi (instrumental pieces), lyrical folk songs. It is noted that the main reason for Khan Shushinsky's success is not only that he has a wide range of voices, but also to acquaint a wide audience with the genres of traditional Azerbaijani oral music and bring folk singing to a high level of art. It is noted that Khan Shushinsky achieved great success in studying, performing, and promoting Azerbaijani national music as a result of many years of singing experience. The article also notes that the art of Karabakh singing, especially the special music schools operating in Shusha in the middle of the XIX century, played an important role in the formation and development of Khan Shushinsky as an artist. One of the most important points is that Khan Shushinsky has a beautiful and charming, wide range of sounds, which is superior to other singers, and the singer can easily play the bells, which indicate the ability to sing. Khan Shushinsky's perfect knowledge of classical oriental poetry, his choice of ghazal poems under the harmony of mugam, and his clear pronunciation are indicators of his style of performance. The article explains that the cadence formulas are used with special precision to convey the content and character of the mughams sung by Khan Shushinsky, and the original timbre is expressed as an important means of the singer's unique style of performance derived from national music.

Key words: Khan Shushinsky, creativity, mugam singer, khanende, folk songs, dastgah.

Бейімханум ВАЛІСВА, orcid.org/0000-0002-5076-5138 старший викладач Азербайджанської начіональної консерваторіі (Баку, Азербайджан) veliyeva_b@mail.ru

\section{ВПЛИВ ТВОРЧОСТІ ХАНА ШУШІНСЬКОГО НА РОЗВИТОК АЗЕРБАЙДЖАНСЬКОЇ СПІВОЧОЇ ШКОЛИ (ХАНЕНДЕ)}

У статті досліджується творчість видатного представника азербайджанської співочої школи, співакаханенде Хана Шушінського (1901-1979 роки життя). Розглянуто особливості співочого стилю Хана Шушінського, широкі можливості діапазону його голосу, принципи виконання мугамов і народних пісень, які є жанром 
традииійної усної музики в Азербайджані. У роботі наголошується на неповторному стилі виконання, багатому репертуарі, вмінні складати пісні за допомогою елементів національної музики, щуо виникли під впливом традицій карабахської співочої школи ХІХ століття на основі творчості Хана Шушінського.

Мета дослідження - визначити принципи виконання Хана Шушінського, особливості інтерпретації мугамов i народних пісень, музичних творів у його виконанні. Ставиться мета розкрити особливості виконавських можливостей Хана Шушінського й визначити його роль у розвитку азербайджанської співочої школи ХХ століття. В основі дослідження лежить детальний науково-теоретичний аналіз стилю Хана Шушінського.

Методологія дослідження трунтується на музично-аналітичному, теоретичному й історичному аналізі, узагальненні досліджень азербайджанських музикознавців із виконавчого стилю мугама.

Наукова новизна дослідження. Уперше як спеціальна дослідницька робота постає проблема вивчення творчості видатного представника азербайджанської співочої школи Хана Шушінського. Водночас творчість Хана Шушінского й середовище, яке його сформувало, розглядалися з позицій східного мистеитва, детально вивчалося виконавське мистеитво співака.

Висновки. Мистецтво виконання мугама має особливе значення в азербайджанській музичній культурі. Співаки зберегли й передали народну музику й мистецтво мугама, яке є виразом духовного світу, інтелекту, бажань і сподівань людей. 3 такого боку творчість Хана Шушінського - важсливий етап у розвитку азербайджанської народної музичної культури. Хан Шушінський, крім вмілого виконавия, був щзе й громадським діячем, творцем багатьох національних народних музичних жанрів, у тому числі тесніфов і ранджи, ліричних народних пісень. Головна причина успіху Хана Шушінського не тільки в тому, щзо він володіє широким діапазоном голосу, але й у тому, щзо він розиирив аудиторію традиційної азербайджанської усної музики, вивів народний спів на високий рівень мистецтва. Хан Шушінський домігся великих успіхів у вивченні, виконанні й популяризації азербайджанської національної музики в результаті багаторічного співочого досвіду. Мистещтво карабахського співу, особливо музичні школи, щзо діяли в Шуші в середині ХІХ століття, зіграли важливу роль у становленні й розвитку Хана Шушінського як художника. Одним із найважливіших моментів є те, щзо Хан Шушінський мав гарний $і$ чарівний голос із широким діапазоном, який перевершував дані інших співаків, співак легко виконував мелізми й складні мелодійні звучання, характерні для мугамного мистецтвв. Досконале знання Ханом Шушінським класичної східної поезії, його вибір віршів-газелей відповідно до гармонії мугама й чітка вимова - показники його стилю виконання. Формули кадениії вимовлялися їм з особливою точністю, щчоб передати зміст і характер мугамов, а оригінальний тембр став засобом вираження унікального стилю виконання співака, запозиченого з національної музики.

Ключові слова: Хан Шушінський, мугам, співак, ханенде, виконавець мугама, класифікація, народні пісні, дестаях.

Introduction. The art of mugam, which embodies the rich cultural values of the Azerbaijani people and the centuries-old history of music, is the most magnificent field of the philosophical and literary direction of Eastern culture. It should be noted that Azerbaijani mugam was included in the List of Oral and Intangible Heritage of Humanity by UNESCO in 2003. The art of mugam, which has a centuries-old history, still exists today as an oral folk art without changing its essence and content. Mugham singers are traditionally called singers in Azerbaijan. It should be noted that the art of mugam and singers are treated with great respect and esteem in Azerbaijan. Singers feel the spiritual and cultural heritage of the people uniquely as if reviving it with their performances.

Although mugam, a branch of Oriental music, is widespread in Azerbaijan, mugham is known as the creative centers of Baku, Shamakhi, Shusha, Ganja, and Nakhchivan. Of particular importance is the Karabakh mugam school formed in Shusha. Most of the Azerbaijani singers are performers born in Karabakh. From this point of view, it is not accidental that Khan Shushinsky, as a brilliant representative of the Karabakh school of singing, has a unique position in the field of mugam singing. Khan Shushinsky's mugam "Karabakh Tragedy" is considered to be the most magnificent performance of the singer's work. Interestingly, many prominent musicians representing the Azerbaijani musical culture were born in Shusha, and these artists often took the nickname Shushali. Khan Shushinsky's pseudonym also comes from here.

Mastering the technique of singing in the folk style, Khan Shushunsky sang Azerbaijani mughams with a twooctave and a half sound range, both in the zither and in the bam. It should be noted that Khan Shushinsky is the first Azerbaijani singer to sing a duet. Khan Shushinsky did not appeal to the works of any composer, except for the songs of Uzeyir Hajibeyli, the founder of the Azerbaijan School of Professional Composing. On the other hand, Khan Shushinsky was the first singer to perform with a symphony orchestra. From this point of view, the role of the famous singer in the development of the art of singing with rich national traditions is important.

Recent research and publications analysis. Although it is important to study the work of Khan Shushinsky, who played an important role in the development of the art of singing in Azerbaijan, this topic has been considered by various musicologists when studying folk music. Therefore, in the process of research, the scientific basis of the article presented by Azerbaijani musicologists A. Abdullazade, E. Babayev, R. Zohrabov, R. Imrani, G. Akhundova, F. Shushinsky, V. Abdulgasimov, A. Aslanoglu. 


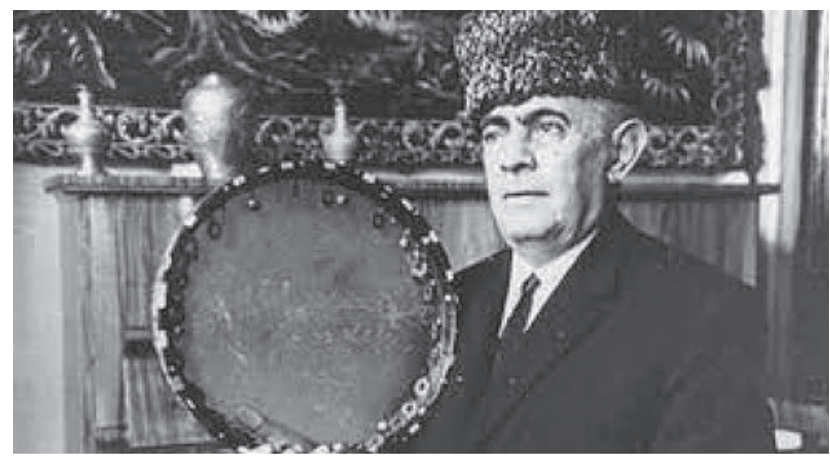

Fiq. 1. Khan Shushinski. Baku

The purpose of the research. The purpose of the research is to study the work of Khan Shushinsky, the leading artist of the Azerbaijani school of singing. During the research process, Khan Shushunsky's repertoire, performance features, as well as classifications, and songs composed were considered. The article highlights the singer's hitherto unexplored work in the context of the development of the mugam genre within the framework of Azerbaijani music science and examines its peculiarities.

Presentation of the main material. One of the masters occupying a special place among the Karabakh khans is Khan Shushinsky. The reason for the great success among the people of Hanom Shushinsky was not only a wide range of his voice, but also the acquaintance of the masses with the classical music and culture of Azerbaijan. He raised folk singing to the highest level of art.

Thanks to the long-term experience of singing, Khan Shushinsky achieved great success on the path of deep study, performance, and propaganda of Azerbaijani national music. He was an ingenious connoisseur of many folk melodies, rich and complex mugams. The other Khanende was not easy to compete with Hanom Shushinsky in the field of a workshop performance of ancient folk songs, tesniphs, and especially mugams. He mastered the technique of vocals in the full sense of the word.

Khan Shushinsky had a powerful, rarely encountered voice. Many famous khans envied him as Khan manages his voice and with some technical skill, he fills with trellis. His divine voice was so overflowing that it reminded me of a fountain.

It is safe to say that after Jabbara Garyagdyoglu and Seyida Shushinsky in the history of our national culture there was no other second khan, who would have performed rhythmic mugams with such a huge taste, as Khan did. The role of Jabbar Qaryagdioglu in the development of the art of mugam and singing should be specially noted:

" $<\ldots>$ The merit of Garyagdioglu is that has changed the form and place of performances, he adapted the traditional mugham repertoire for stage performances and thus contributed to the institutionalization of mugham singing" (Strzemżalska, 2021: 224).

The art of Khanende cannot be imagined without a tambourine. Khanende, who does not know how to play the tambourine, will not be able to cope with rhythmic mugams. Because the voice of the Khanende must be combined with the rhythm of the tambourine. If a khanende performing rhythmic mugam does not know how to play the tambourine, then he will not be able to correctly perform the mugam rhythm, and as a result, mugam will not only lose its freshness but will also sound wrong. As musicologists said, Khan Shushinsky was an incomparable performer of mugams, thanks to his perfect physiology. Khan could set a wonderful rhythm on the tambourine. Those who took part in the old Karabakh weddings remember that Khan Shushinsky brought the audience into ecstasy not only with his velvet voice and beautiful appearance but also with his masterful tambourine playing.

We believe that one of the topical issues is the study of the creative environment, which played an exceptional role in the maturation of Khan Shushinsky as a khanende, and in this article, we will talk about the musicians who influenced the formation of his work, and, having set ourselves the goal of studying the features of the development of the performance of mugam and especially the art of khanende in Azerbaijan in the second half of the 19th - early 20th centuries, we will try to present a real picture of the musical life of that period.

An indisputable fact is that the 19th century is characterized as a period of significant changes, positive achievements in the field of performing Azerbaijani mugham. Musical meetings and the activities of schools in the field of vocal and instrumental performance of mugham in various cities have accelerated this process. During that period, the Karabakh (Shusha) mugham performers gained popularity not only in Azerbaijan but also abroad. The relationship between mugam singers is characterized as follows: " $<\ldots>$ musicians - primarily khanende, tarist (tarzen), ashig, as well as kyamanchists and performers on other musical instruments - are mentioned in a form, on the one hand, demonstrating good acquaintance, friendship and trusting relationship between the poet and musicians, the poet's admiration for their work, and on the other hand, implying the knowledge of these personalities by all readers <... >"(Bayramova, 2019: 207).

In this article, we will tell you about the khanende who lived and worked in that period, whose work was little studied. 
The term Karabakh school of mugham, to which Khan Shushinsky belongs, means schools associated with the names of individual khanende, which perpetuate their style of performance and pass on the traditions of mugham and art secrets from generation to generation. The mugham school of professional performers is a real school of art. It is also worth noting that the life and work of the khanende, known to us as representatives of the Karabakh school of mugham, are mainly associated with the city of Shusha. The expressions "Who cannot sing is not a Shusha citizen", "Even the crying of babies in Shusha is built on mugam" have become popular sayings. Indeed, khanende gained experience thanks to the cultural environment, musical life, customs, and traditions of this city.

It is no coincidence that when studying the Karabakh art of khanende, in comparison with its other regions, a wider place is given to the art of khanende, whose life is connected with the music of Shushi. Because it is necessary to take into account the great role of the rich musical culture of Shushi in the $19^{\text {th }}-20$ th centuries. in the development of culture not only of Azerbaijan but also of other peoples of the Transcaucasus. We also note that Shusha was the cultural center of Karabakh, due to which such examples of traditional art as mugham, ashug, folklore, and others, developed here. Therefore, famous musicians, khanende, and instrumental performers living in other regions of Karabakh often came to the city of Shusha and took part in grandiose art competitions.

It is known from written sources obtained in the course of researching the work of Khan Shushinsky that even in the 19th century Shusha was a cultural center, due to which special attention was paid here to public education. In this regard, Aliverdibekov writes: "Much attention is paid to public education in Shusha, a school is open in every quarter. In these schools, attention is paid to poems and poetry. During the training, the works of Firdovsi, Sedi Hafiz, and other famous poets are studied. Poetry contests are organized in schools, talented students line up in two rows, and each row tries to surpass the enemy.

As an example of such schools, one can show the schools of Molla Kelbkli, Mirza Aligulu, Molla Hamdi, Mirza Kerim, Molla Ali Khalifne, and others. In addition to poetry and poetry, extremely great attention was paid to the theory of music. Among the music schools were the schools of Navvab Mir Mokhsun, Aga Ibn Haji Seyid Ahmed Garabigina" (Shushinsky, 1985: 480).

From the above, we can conclude that adolescents from a young age studied poetry and music. In addition, we note that oral traditional musical art also created great opportunities for attracting local children to the art of mugham. Therefore, the Karabakh masters, and especially the khanende, have known mugam and poems since childhood. The logical result of just such an education was that Khan Shushinsky always found and chose gazelles and goshmas, corresponding to the spirit and essence of mugham. He brilliantly performed samples from the works of such classical poets as Magomed Fizuli, Molla Panah Vagif, Gasim bey Zakir, Seyid Azim Shirvani, Samed Vurgun.

At musical meetings, that is, at the Majlises, which constituted the basis of the creative environment in which Khan Shushinsky grew up, interesting conversations about literature, painting, and the art of music were held, and sometimes these conversations turned into discussions. These meetings were different from banquets and weddings. Here more attention was paid to the aesthetic problems of the art of music. The role of the Majlises can be described as follows: "Artistic forms and techniques were developed at the Majlises, including the formation of new norms for singing Azerbaijani mugam, which we can listen to today in a more or less modified form. Each of the cultural centers could boast of its mugam repertoire and style of performance, which differed from the performance in neighboring regions in the set of melodies and general sound" (Strzemżalska, 2021: 224).

Destgakhi mugam is being improved, enriched by various departments and thickly, new tesniphs and colors are being created. Here outstanding musicologists, versed in the intricacies of oriental music, took care of the correct and masterful singing of the khanende. At musical meetings, the performance of the mugams "Shur", "Rast", "Mahur", "Chahargah", "Bayaty-Isfahan" took two, and sometimes three hours.

During the meetings, mugam was performed by several khanende, and experts in mugam expressed their opinion about the performance, criticized mistakes. Sometimes a competition was announced for the performance of a certain dastgah. Therefore, each khanende and performer made efforts to study and improve their art more deeply. Often, musicians taking their first steps in creativity received blessings from the local art masters.

Information about this is contained in the following books: "Vyuzukh-ul Argam" by Navvabi, "People's Musicians of Azerbaijan" by F. Shushinsky, "The history of the emergence and development of the genre of Azerbaijani mugham" by R. Imrani. In the sources provided, the great role of these schools in the formation of the Karabakh school of art of khanende is noted. 
Speaking about those singers who played a role in the formation of Khan Shushinsky as a khanende, they, first of all, call his teacher Islam Abdullayev, known as Segah Islam. At the same time, the indisputable fact is that such famous khanende of that time as Seyid Shushinsky and Jabbar Garyagdioglu influenced the work of Khan Shushinsky. The khanende himself also considered them to be his masters and in all interviews and conversations throughout his life noted that he had learned from them. However, it is worth noting that along with these great masters, a generation of khanende lived and worked in Karabakh at that time, information about which has come down to our time thanks to the books of Firudin Shushinsky. During his lifetime, the author himself repeatedly noted that it was Khan Shushinsky who informed him about the musicians whose names are named in the book and who were not known among the general public. This proves once again that these musicians played an important role in the further creativity, the creative experience of the khanende, who from an early age listened to their performance. Mashadi Isi, who is one of them, is known as a master khanende who mastered mugam at a high level. He performed Rast dastgah. "Shur", "Humayun" and especially "Mahur" in its characteristic form. Highly appreciating the talent of the khanende Meshedi Isi, Jabbar Garyagdioglu wrote: " $<\ldots>$ Khanende Mashadi Isi, who is one of the disciples of the famous in the city of Shusha and throughout the Caucasus, Harrat Gulu, solemnly performed dastgah" Mahur" (Shushinsky, 1985: 480). He was considered the most successful khanende in the field of performing tesniphs and playing the tambourine.

Mashadi Isi, with free diction, clearly communicated the words of the songs he performed to the audience. Along with the gazelles and goshma of poets, he performed the works of Hafiz and Sedi with inspiration, charming his listeners. According to Jalilbek Bagdabekov's notes, Meshedi Isi performed the poems of Azerbaijani poets for the first time.

Mashadi Isi received invitations to weddings and celebrations not only in Karabakh, but also in many cities of Azerbaijan - Ganja, Agdash, Shemakha, and Baku. Mashadi Isi sang for months at the celebrations of Mahmud Agha Shemakhinsky and was invited several times to the city of Tehran by the Iranian judge Nasreddin Shah. Having won a competition held between Iranian singers in the Shah's palace, Meshedi Isi was awarded the Shiri-Khurshid order.

In addition to the fact that Mashadi Isi was a great mugham master, he also occupies a special place among the classical Azerbaijani khanende as a tesniphkhan. As you know, the authors of the tesniphs were the khanende. Many Tesnifs of Mashadi Isi are known, especially the Tesnifs "Rast", "Mahur". He composed tesniphs for some samples of folk literature, especially for the Muhammases and goshma of Vagif, Zakir.

Of course, Mashadi Isi's voice was not as high as the voice of Haji Hyushu, Bulbuljan. However, he charmed the audience, as he knew the mugam technique well. Mashadi Isi was a perfect master. His contemporary Chirag Magomed Shushinsky said that he is a master of khanende:

"Mashadi Isi's voice was not very high. However, he performed all mughams masterfully. There is hardly another khanende in the world who could perform" Osmanli "the way Meshedi Isi did" (Shushinsky, 1985: 480).

Another musician who left his mark on the work of Khan Shushinsky - Abdulbagi Bulbuljan Karbalai Alioglu Zulalov, was born in 1841 in the city of Shusha. Abdulbagi received his first musical education at the Harrat Gulu school. After leaving school, he, together with Tarzan Sadikhdjan, began performing at celebrations, national celebrations in Karabakh, Sheki, Shirvan, and Ganja. This master had both an excellent voice and an attractive appearance and high stage culture. It is no coincidence that he won the favor of his contemporaries, including the poet Natavan. Abdulbagi took part in the celebrations held in the garden of Khan gizi Natavan, including in the folk celebrations organized in honor of the water in the city of Shusha (August 18, 1873).

At the beginning of 1875, Abdulbagi moved to the city of Tiflis. Charity concerts were often held in Tiflis, which is considered the cultural center of Transcaucasia. Famous Russian and Italian singers and musicians performed at these concerts along with local khanende.

For the first time in Tiflis, Abdulbagi sang accompanied by the great tarzen Sadykhdjan. After the first performance, they became famous not only in Tiflis but throughout Georgia. In a short time, it has become a favorite of various categories of the population. In a short time, Abdulbagi perfectly learned the Georgian language. He delights Georgian listeners with his singing.

Very quickly Abdulbagi won such fame that in Tiflis he was called "Bulbuljan". Together with Tarzan Sadikh, he took part in charity concerts organized for poor Muslims. At that time, the newspaper "Ziya", published in Tiflis, previously published posters of concert performances with the participation of Abdulbagi and Sadykhdzhan. Consider one of these newspaper ads:

"To provide material assistance to the Iranian hospital built in Tiflis for the poor, various 
performances will take place in the building of the Tiflis Theater on the 8th of this month. Khanende will perform mugam in European and Eastern songs, among the participants will also be Khanende and Sazandar Abdulbagi and Sadikh, who are the favorites of the population. For the first time, Muslims of Tiflis and Iran will enter the honorable stage of prosperity.

In May 1900, Abdulbagi was among the famous khanende's present at the big mejlis organized in the palace garden in honor of the arrival of the ruler of Iran Muzafaraddin Shah in Tiflis. At this event, Abdulbagi sang with such skill that Muzafaraddin Shah was delighted. He awards Abdulbagi with the ShiriKhurshid order for mastering the art of khanende.

Bulbuljan had a wide and comprehensive repertoire. He sang not only in Azerbaijani but also in Georgian, Armenian, Kumyk, and Persian. He was invited to Armenian, Georgian, and even Russian celebrations. The famous Armenian musicologist V. Karganov, highly appreciating the voice and repertoire of Bulbuljan, wrote: "The repertoire of the best khanende of Tiflis Abdulbagi found a way to the heart of any "Bijo" and "Kinto". Khanende enchanted not only the inhabitants of the city with his abilities but also charming beauties".

In his memoirs "Old Azerbaijani Music", Jabbar Garyagdioglu writes: "Disciple Harrat Gulu, known throughout the Caucasus as a khanende Abdulbagi Zulalov solemnly performs dastgah "Zabul". When switching to "Khasar" he sang in such a voice that no one else could sing. Because "Hasar" is a song that requires overflows, and Abdulbagi performed this mugam with dignity, thanks to his beautiful voice with overflows" (Shushinsky, 1985: 480).

Another khanende, whose singing influenced Khan of Shushinsky, Jamshed, was from the village of Malybeyli, therefore he was called "Malybeyli Jumshud". He performed dastgah in a manner peculiar only to him and brought Azerbaijani mugams to the listener through the emotional expression of the musical drama that is like mugham. From this point of view, "Orta Mahur", "Shushter", and rhythmic mughams "Heyraty", "Ovshary" and "Karabakh Shikestesi" are characteristic. Jamshed skillfully performed these mugams. Since Jamshed was from a village, he always gravitated towards rural weddings. Therefore, he paid special attention to the performance of ancient folk songs. Because at that time, in comparison with mugams, folk melodies were closer to the spirit of the rural population.

In 1913, the well-known Azerbaijani Azerbaijan Malybeyli Jamshed was invited to Kyiv by the "Extra phone" joint-stock company to record his voice on a disc. Jamshed went to Kyiv and recorded on a gramophone record a brilliant performance of the mugams "Segah", "Mahur", "Rast", "Shikayeti-Fars" and several tesniphs.

In addition to the above-mentioned khanende, such musicians as Zabul Gasim, Segah Islam, Shukur's grandson of Rovshan, Veskhan Jalil influenced the formation of Khan Shushinsky's creativity. The questions that we touched upon above once again show that the Karabakh land, where Khan Shushinsky was born and raised, and the Shushi musical school played an exceptional role in the formation of Khan Shushinsky as a master, and the diversity of his work.

Conclusions. Thus, some interesting aspects are revealed when studying the work of Khan Shushinsky. Khan Shushinsky has been one of the irreplaceable composers and singers of the art of mugam since the early twentieth century. Khan Shushunsky's art, representing the Karabakh school of singing, benefited from folk art. $\mathrm{He}$ is a singer of mugam and folk songs, a rare pearl of folk music, and also created many songs. Thus, these trends in Khan Shushinsky's work are one of the main characteristics of the artist. We can note that Khan Shushinsky, a skilled performer of the "Segah" mugam, performed all types of this mugam. On the other hand, the singer is the author of such songs as "Mountains of Shusha", "Gamarim". The fact that these songs are based on folk intonations and national elements has led to their acceptance as folk songs. It should be noted that the laconic lyrics and playful movement of these songs have led to the emergence of other singers in a short time. As a musician, Khan Shushinsky understood that folk music plays an important role in the aesthetic education of the people, inspires them to life, arouses optimism. Therefore, Khan Shushinsky's performance based on folk traditions played an important role in the development of the art of singing in Azerbaijan with its harmony, clarity, and fullness. Features of Khan Shushinsky's style of performance, unique singing style, new additions to folk songs, played a direct role in the development of the national art of singing and were valued as a novelty in the performing arts. Khan Shushinsky's work was formed and developed under the influence of the mugam genre. Khan Shushinsky was an example for all singers of the time as a skilled mugham connoisseur, mastering all the laws of mugam and benefiting from the work of his predecessors. Khan Shushinsky managed to create his improvisational features by performing mugam correctly.

The singer's mastery is reflected not only in her performance style and thinking, but also in her unique style of performance, bells, long breath, improvisation. Khan Shushinsky's deep knowledge of all the features of mugam performance, his perfect knowledge of the laws of melodic development, his ability to sing rich 
and complex melodic melodies are the main features of the singer. Khan Shushinsky was able to apply in his performance the important melodic expressions that form the basis of the sections within the mugam, mastering the passages perfectly. Khan Shushinsky managed to prevent the assimilation of the national spirit of folk music, preserving the originality of the art of mugam. As a singer, he preserved the traditions of the art of mugam, developed them, and enriched them with new melodic features. Khan Shushinsky managed to create an original school of performance with his way and style in art.

From this point of view, it can be considered that Khan Shushinsky's creative heritage is an important stage in the development of the art of singing based on traditions, and each of his folk songs and mugam samples is of great importance in the field of folk art. Representatives of the later period of the Azerbaijani school of singing continue the traditions of Khan Shushinsky's performance style perfectly and uniquely.

\section{BIBLIOGRAPHY}

1. Abdulqasımov V. Qəzəl janrının xanəndə ifaçılıgında təzahürü. Konservatoriya jurnall. 2009. No. 5-6. S. $138-146$.

2. Abdullazade G. Qedim ve orta esrlerin musigi medeniyyeti. Baku : Qartal, 1996. 288 s.

3. Axundova G. Azərbaycanda xanəndəlik və vokal mədəniyyəti ənənələrinin yaranması və inkişafı. Baku : "Nurlar", 2009, $160 \mathrm{~s}$.

4. Aslanoğlu A. Muğam və bilik poetikası. Baku, 2004. $296 \mathrm{~s}$.

5. Babaev E. Әnənəvi musiqi - müşahidələr və fikirlər. Baku : Nauka, 2000.116 s.

6. Babayev E. Azərbaycan muğamlarında və dəstgahlarında ritm və intonasiya problemləri. Baku : Ergün, $1996.126 \mathrm{~s}$.

7. Babayev E. Azərbaycanın ənənəvi şifahi musiqisində intonasiya problemləri. Baku : Elm, 1998. $145 \mathrm{~s}$.

8. Байрамова А. Мугам и ашугское искусство в Азербайджанской поэзии XIX-XX веков. Грамота. 2019. № 5 (12). C. 206-211.

9. Hacıbəyli U. Azərbaycan xalq musigisinin əsasları. Bakı : Yazıçı, 1985.

10. İmrani R. Muğam tarixi. Bak1 : Elm, 1998.

11. Shushinsky F. Azerbaycan xalq musigiçiləri. Yaziçı, 1985.

12. Strzemżalska A. Jabbar Garyagdioglu and Bulbul: from the history of formation of the Azerbaijani singing school (late 19th - first half of the 20th centuries). History, archaeology and ethnography of the caucasus. 2021. V. 17. № 1. P. 222-235.

13. Vəliyeva B. Xan Şuşinskinin mahnı yaradıcılığı ifasında zərbi muğamlar. Konservatoriya jurnalı. 2015. No. 1 (27). S. 49-54.

\section{REFERENCES}

1. Abdulqasimov, V. (2009). Qezel janrinin xanende ifachiliginda tezahuru. [Manifestation of ghazal genre in singer's performance]. The journal of Conservatory, № 5-6, pp. 138-146. [in Azerbaijani].

2. Abdullazade, G. (1996). Qedim ve orta esrlerin musigi medeniyyeti. [Ancient and medieval music culture]. Qartal [in Azerbaijani].

3. Axundova, G. (2009). Azerbaycanda xanendelik ve vokal medeniyyet enenelerinin yaranmasi ve inkishafi. [Revival and development of khanende traditions and vocal culture in Azerbaijan]. Nurlar [in Azerbaijani].

4. Aslanoglu, A. (2004). Muğam və bilik poetikası [Mugamin poetics and cognition]. Elm [in Azerbaijani].

5. Babayev, E. (2000). Onənəvi musiqi - müşahidələr və fikirlər. [Traditional music - observation and opinion]. Elm [in Azerbaijani].

6. Babayev E. Azərbaycan muğamlarında və dəstgahlarında ritm və intonasiya problemləri [Problems of rhythm and intonation in Azerbaijani mughams and devices] B.: Elm, 1998. $145 \mathrm{~s}$ [in Azerbaijani].

7. Babayev, E. (1998). Azərbaycanın ənənəvi şifahi musiqisində intonasiya problemləri. [Problems of intonation in traditional oral music of Azerbaijan]. Elm [in Azerbaijani].

8. Bayramova, A. (2019). Muqam i ashuqskoe iskusstvo v Azerbaydjanskoy poeziii XIX-XX vekov. [Mugam and ashig art in Azerbaijan poetry of the XIX-XX centuries]. Qramota, № 5 (12), pp. 206-211. https://doi.org/10.30853/ manuscript.2019.5.43 [in Russian].

9. Hajibeyli, U. (1985). Azerbaycan xalq musigisinin esaslari.[Basics of Azerbaijani folk music]. Yazichi [in Azerbaijani].

10. İmrani, R. (1998). Mugam tarixi. [History of mugham]. Elm [in Azerbaijani].

11. Shushinsky, F. (1985). Azerbaycan xalq musigichileri. [Azerbaijani folk musicians]. Yazichi [in Azerbaijani].

12. Strzemżalska, A. (2021). Jabbar Garyagdioglu and Bulbul: from the history of formation of the Azerbaijani singing school (late 19th - first half of the 20th centuries). History, archaeology and ethnography of the caucasus. V. 17. № 1, 2021. pp. 222-235.

13. Veliyeva, B. (2015). Xan Shushinskinin mahni yaradiciliği ifasinda zerbi mugamlar. [Song creation by Khan Shushinsky]. The journal of Conservatory, 1 (27), pp. 49-54. [in Azerbaijani]. 